\title{
SISTEM INFORMASI PENDATAAN ALAT BANTU BAGI PENYANDANG DISABILITAS PADA DINAS SOSIAL ACEH
}

\author{
Aprillian Windy Anggara \\ Program Studi Manajemen Informatika, Fakultas Ilmu Komputer, AMIK Indonesia, \\ Jl. T Nyak Arief Sp Mesra No. 400, Kota Banda Aceh, Indonesia. \\ Email: aprilianwindy_anggara@gmail.com
}

\begin{abstract}
Abstrak
Salah satu instansi yang hanya memanfaatkan sistem informasi secara manual dengan menggunakan aplikasi Miscrosoft word dan Excel pada pendataannya dilakukan Dinas Sosial Aceh, yang menyangkut dengan Sistem Informasi Pendataan Alat Bantu bagi Penyandang Disabilitas yang mengakibatkan proses pembuatan laporan menjadi terlambat karena harus membuka banyak folder dan file-file untuk mengumpulkan data-data sesuai dengan bentuk laporan yang diinginkan Pimpinan. Dari uraian maka yang menjadi tujuan penulisan yaitu untuk mengetahui dan merancang Sistem Informasi Pendataan Alat Bantu Bagi Penyandang Disabilitas pada Dinas Sosial Aceh dengan menggunakan Bahasa pemrograman berbasis web. Ada dua metode yang penulis gunakan untuk mengumpulkan data yaitu; studi lapangan dan studi pustaka. Berdasarkan hasil pengamatan dan penulis dapat menarik suatu kesimpulan yang diantaranya adalah Proses pendataan bantuan alat disabilitas dengan menggunakan sistem berbasis online lebih mudah dilakukan Karena didukung dengan pelaporan khusus bagi bantuan alat disabilitas dan aplikasi dibangun dengan menggunakan bahasa pemrograman berbasis web seperti, PHP, HTML, CSS, Java Script dan MySQL sebagai databasenya.
\end{abstract}

Kata Kunci: Sistem, Informasi; Bantuan Alat; Disabilitas.

\begin{abstract}
One agency that only utilizes the information system manually using Microsoft Word and Excel applications in its data collection is carried out by the Aceh Social Service, which is related to the Assistance Data Collection Information System for Persons with Disabilities which results in the process of making reports being late because they have to open many folders and files. files to collect data in accordance with the desired report from the leadership. From the description, the purpose of writing is to find out and design a Data Collection Information System for Assistive Devices for Persons with Disabilities at the Aceh Social Service using a web-based programming language. There are two methods that the authors use to collect data, namely; field studies and literature studies. Based on the results of observations and the author can draw a conclusion that includes the data collection process for disability tools using an online-based system that is easier to do because it is supported by special reporting for the assistance of disability tools and applications are built using web-based programming languages such as PHP, HTML, CSS., JavaScript, and MySQL as the database.
\end{abstract}

Keyword: Systems; Information; Assistance Tools; Disabilities.

\section{Pendahuluan}

Perkembangan kehidupan manusia pada masa sekarang ini tidak lepas dari kemajuan teknologi. Semakin maju dan berkembangnya teknologi yang digunakan maka semakin cepat proses penyelesaian suatu pekerjaan [1]. Salah satu peran utama teknologi adalah sistem informasi yang saat ini telah menjadi kebutuhan pokok dalam dunia kerja [2], karena telah menjadi urat nadi 
kelangsungan suatu pekerjaan baik dalam instansi pemerintahan maupun instansi non pemerintahan.

Dengan berkembangnya teknologi saat ini komputerisasi merupakan suatu alternatif yang tepat untuk kebutuhan pekerja yang menuntut kecepatan, ketepatan dan efisiensi waktu [3]. Oleh karena itu setiap instansi sangat memerlukan sistem informasi berbasis komputerisasi untuk memudahkan pekerjaan [4]. Mengolah dalam jumlah banyak tentunya sangat sulit tanpa adanya sebuah aplikasi pendukung dalamnya [5]. Hal ini mendorong banyak organisasi atau instansi memanfaatkan perkembangan sistem informasi secara maksimal, baik informasi yang berasal dari dalam maupun informasi yang berasal dari luar.

Salah satu instansi yang hanya memanfaatkan sistem informasi secara manual dengan menggunakan aplikasi Miscrosoft word dan Excel pada pendataannya dilakukan Dinas Sosial Aceh, yang menyangkut dengan Sistem Informasi Pendataan Alat Bantu bagi Penyandang Disabilitas yang mengakibatkan proses pembuatan laporan menjadi terlambat karena harus membuka banyak folder dan file - file untuk mengumpulkan data - data sesuai dengan bentuk laporan yang diinginkan Pimpinan. Dari uraian diatas maka yang menjadi tujuan penulisan yaitu untuk mengetahui dan merancang Sistem Informasi Pendataan Alat Bantu Bagi Penyandang Disabilitas pada Dinas Sosial Aceh dengan menggunakan Bahasa pemrograman berbasis web.

\section{Metode Penelitian}

Kegiatan penelitian ini dilakukan pada tahun 2017 yang saat itu penulis sedang melakukan Program Praktek Lapangan (PPL) di AMIK Indonesia. Pengumpulan data yang diperlukan dalam penulisan laporan [6] ini diperoleh dengan dua metode yaitu studi kepustakaan yang berkaitan dengan literatur-literatur buku-buku perpustakaan dan karya ilmiah lainnya, studi lapangan dengan melaksanakan interview dan observasi langsung terhadap objek yang berhubungan dengan penelitian ini. Rancangan penelitian yang digunakan adalah penelitian terapan, dimana bertujuan untuk menguji teori atau suatu ilmu yang sudah ada untuk keperluan praktis dan dapat bermanfaat secara langsung dalam praktik di dunia nyata. Tujuan dari penelitian terapan (applied research) yaitu jenis penelitian yang diarahkan untuk mendapatkan informasi yang dapat digunakan untuk memecahkan suatu masalah [7]. Sedangkan desain penelitian menggunakan metode eksperimental karena menghasilkan sebuah produk yaitu aplikasi pendataan alat bantu bagi penyandang disabilitas.

\section{Hasil dan Pembahasan}

\subsection{Analisis Sistem}

Analisa merupakan tahap yang menemukan teknik penguraian komponen-komponen untuk mencapai suatu tujuan [8], setelah kebutuhan dari suatu permasalahan telah teridentifikasi, studi kelayakan terpenuhi hingga batasan-batasan analisis terhadap yang akan di implementasikan ke dalam suatu pemograman $[9,10]$. Analisis dilakukan untuk memperoleh informasi tentang yang sedang berjalan dibidang administrasi dimana informasi yang dikumpulkan terutama mengenai kelebihan dan kekurangan yang berlaku sehingga nantinya dapat menghasilkan informasi baru yang efektif dan efisien [11].

Pada tahap ini juga di uraikan tentang beberapa prosedur atau tahap dalam menjalankan pendataan Bantuan alat penyandang disabilitas dilengkapi dengan FlowMap tentang yang sedang berjalan dan usulan pada Dinas Sosial Aceh. FlowMap merupakan bangan arus yang menunjukkan struktur umum dari sebuah informasi, yang menampilkan uraian umum urutan pemprosesan data dalam bentuk umum dan menunjukkan arus pekerjaan secara keseluruhan.

Berdasarkan hasil pengamatan langsung pada Dinas Sosial Aceh. Sistem yang sedang berjalan pada Dinas Sosial Aceh sampai saat ini sudah menggunakan sistem secara terkomputerisasi, 
terutama dalam melakukan penginputan data bantuan alat penyandang disabilitas tetapi hanya pada penggunaan aplikasi Microsoft Office Excell. Dinas Sosial Aceh saat ini telah memiliki sebuah komputer sebagai alat bantu, tetapi komputer tersebut hanya digunakan untuk melakukan pengetikan surat dan tidak untuk melakukan penginputan data untuk Bantuan alat penyandang disabilitas baru dikarenakan tidak adanya aplikasi yang mendukung pada komputer tersebut.

\subsection{Prosedur Pengolahan Data}

Analisis sistem yang berjalan merupakan kegiatan penguraiaan suatu sistem informasi yang utuh dan nyata kedalam komponen-komponen yang bertujuan untuk mengidentifikasi serta mengevaluasi masalah-masalah yang muncul [12], hambatan-hamabatan yang mungkin terjadi dan kebutuhan-kebutuhan yang diharapkan. Analisis sistem sangat tergantung pada sebuah landasan konseptual sehingga mengarah kepada suatu solusi untuk perbaikan maupun pengembangan kearah yang lebih baik dan sesuai dengan kebutuhan serta merancang output yang sedang digunakan untuk mencapai tujuan yang sama dengan seperangkat input lain sehingga menjadi lebih sederhana dan lebih interaktif.

Setelah penulis mengadakan kerja praktek dan menganalisa sistem yang sedang berjalan pada Kantor Dinas Sosial Aceh, sistem pendataan masih menggunakan program aplikasi Microsoft Word dan Excel. Sehingga kurang efektif karena banyak data yang bercampur dan menyulitkan staff dalam mencari data penduduk yang sudah terdata, dan data yang sudah diketik masih disimpan dalam file yang bersamaan

\subsection{Perancangan Sistem}

Perancangan sistem merupakan suatu kegiatan pengembangan prosedur dan proses yang sedang berjalan untuk menghasilkan suatu sistem yang baru, atau memperbaharui sistem yang ada untuk meningkatkan efektifitas kerja agar dapat memenuhi hasil yang digunakan dengan tujuan memanfaatkan teknologi dan fasilitas yang tersedia $[13,14]$. Pada bab ini penulis akan memberikan usulan yang merupakan sistem informasi secara komputerisasi yang diharapkan dapat membantu dan mempermudah pekerjaan.

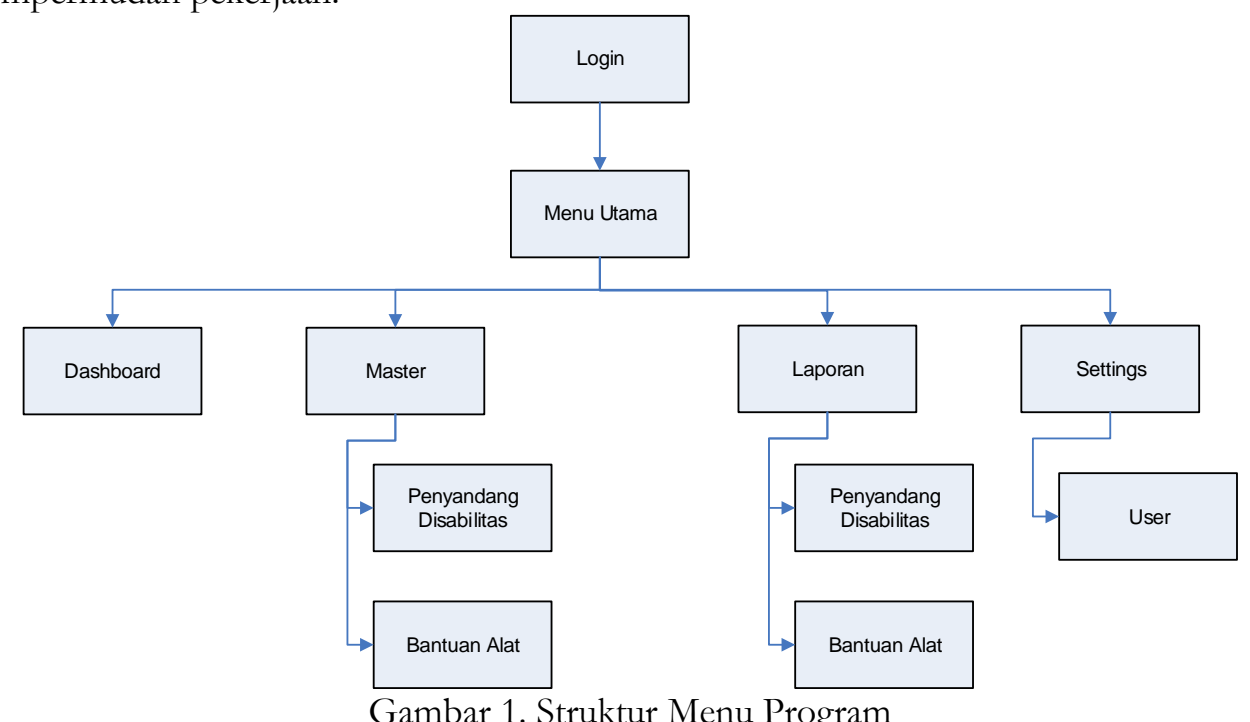

3.4. Perancangan Struktur Data

Tabel 1. Struktur Data Admin

\begin{tabular}{|l|l|l|l|l|}
\hline \multicolumn{1}{|c|}{ No } & Nama Field & Type Data & Size & Keterangan \\
\hline 1 & Users_ID & Int & 11 & Primary Key \\
\hline
\end{tabular}




\begin{tabular}{|l|l|l|l|l|}
\hline 2 & Avatar & Varchar & 50 & - \\
\hline 3 & Nama Lengkap & Varchar & 50 & - \\
\hline 4 & Username & Varchar & 20 & - \\
\hline 5 & Password & Varchar & 20 & - \\
\hline 6 & Website & Varchar & 30 & - \\
\hline
\end{tabular}

Tabel 2. Struktur Data Penyandang Disabilitas

\begin{tabular}{|l|l|l|l|l|}
\hline \multicolumn{1}{|c|}{ No } & Nama Field & Type Data & Size & Keterangan \\
\hline 1 & ID & Int & - & Primary Key \\
\hline 2 & Nama & Varchar & 30 & - \\
\hline 3 & TTL & Varchar & 50 & - \\
\hline 4 & Jk & Varchar & 20 & - \\
\hline 5 & Cacat & Varchar & 20 & - \\
\hline 6 & Alamat & Varchar & 100 & - \\
\hline 7 & Foto & Varchar & 100 & - \\
\hline 8 & Status Kawin & Varchar & 30 & - \\
\hline 9 & Agama & Varchar & 20 & - \\
\hline 10 & Pekerjaan & Varchar & 20 & - \\
\hline 11 & Telepon & Varchar & 12 & - \\
\hline
\end{tabular}

Tabel 3. Struktur Data Bantuan Alat

\begin{tabular}{|l|l|l|l|l|}
\hline \multicolumn{1}{|c|}{ No } & Nama Field & Type Data & Size & Keterangan \\
\hline 1 & ID Bantuan & Int & 11 & Primary Key \\
\hline 2 & ID & Int & 11 & Foreign Key \\
\hline 3 & Keterangan & Varchar & 50 & - \\
\hline
\end{tabular}

\subsection{Tampilan Program}

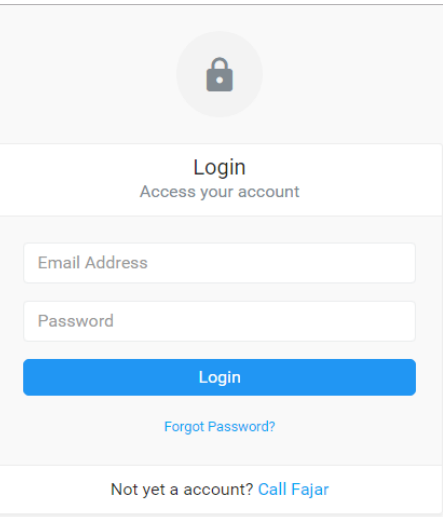

Gambar 2. Form Login 
Jurnal Indonesia : Manajemen Informatika dan Komunikasi

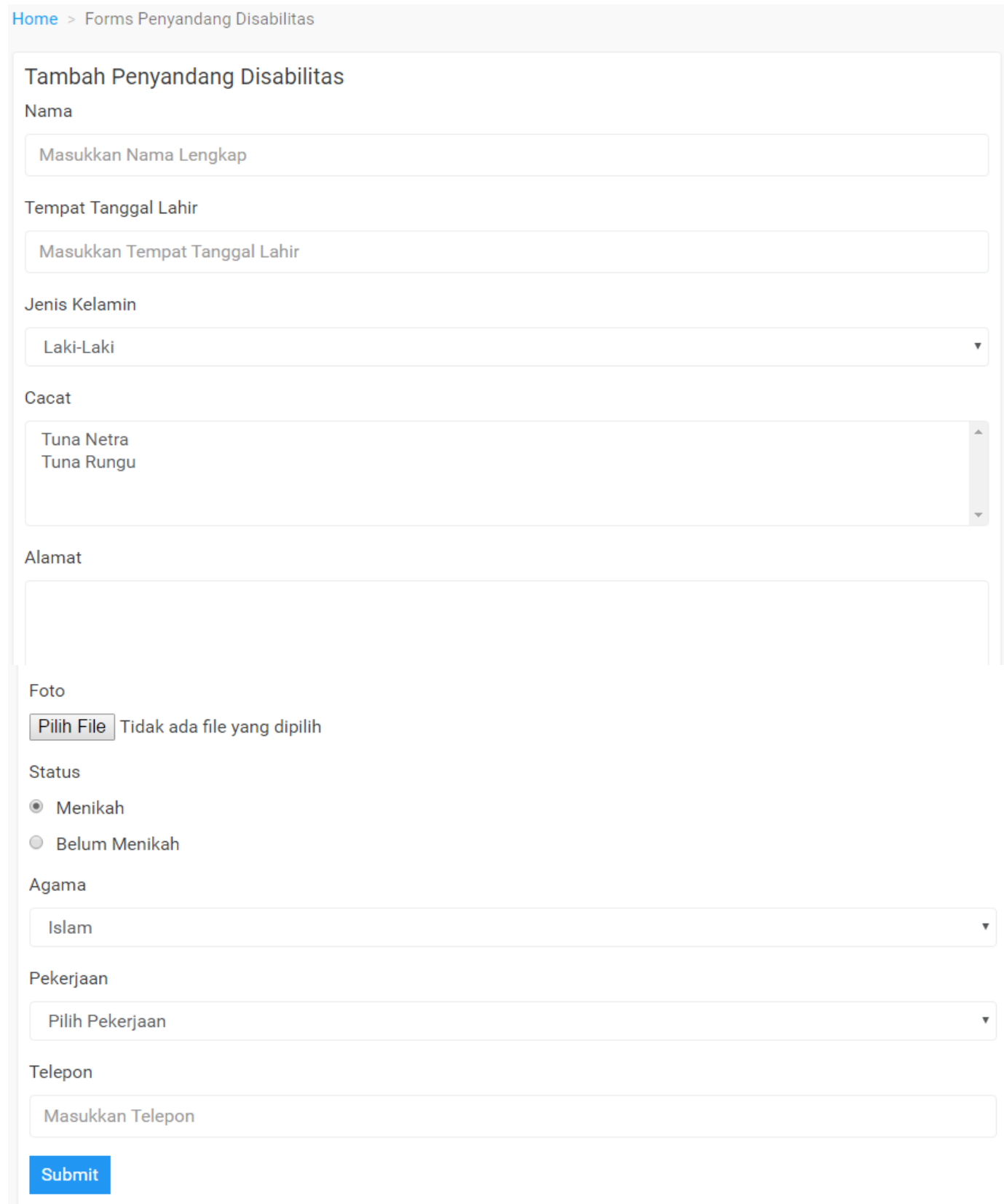

Gambar 3. Form Penyandang Disabilitas

Penyandang Disabilitas Search $\quad$ Q

MASTER
LAPORAN
Bantuan Alat
Penyandang Disabilitas
B Untrings
○ Keluar

Home > Forms Bantuan Alat Penyandang Disabilitas

Tambah Bantuan Alat Penyandang Disabilitas Pilih Biodata Penyandang Disabilitas

Pilih

Keterangan Bantuan

Gambar 4. Form Input Bantuan Alat 


\begin{tabular}{|c|c|c|c|c|}
\hline Penyandang Disabili & litas Search & & 2 & \\
\hline & \multicolumn{4}{|c|}{ Home $>$ User } \\
\hline Penyandang Disabilitas & User Data User & & & \\
\hline $\begin{array}{l}\text { D Bantuan Alat } \\
\text { LAPORAN }\end{array}$ & Avatar & щ & Choose file... & Browse \\
\hline $\begin{array}{l}\text { Bantuan Alat } \\
\text { SETTINGS }\end{array}$ & Nama Lengkap & \multicolumn{3}{|c|}{ Fajar Adista Firji } \\
\hline G User & Email & \multicolumn{3}{|c|}{ ఐ fajaradistifirij@gmail.com } \\
\hline \multirow[t]{4}{*}{ O. Keluar } & Website & (1) & fajaradistifiriji.com & \\
\hline & Username & a & Enter new username & \\
\hline & \multirow[t]{2}{*}{ Password } & a & Enter new password & \\
\hline & & Save & Changes & \\
\hline
\end{tabular}

Gambar 5.. Form User

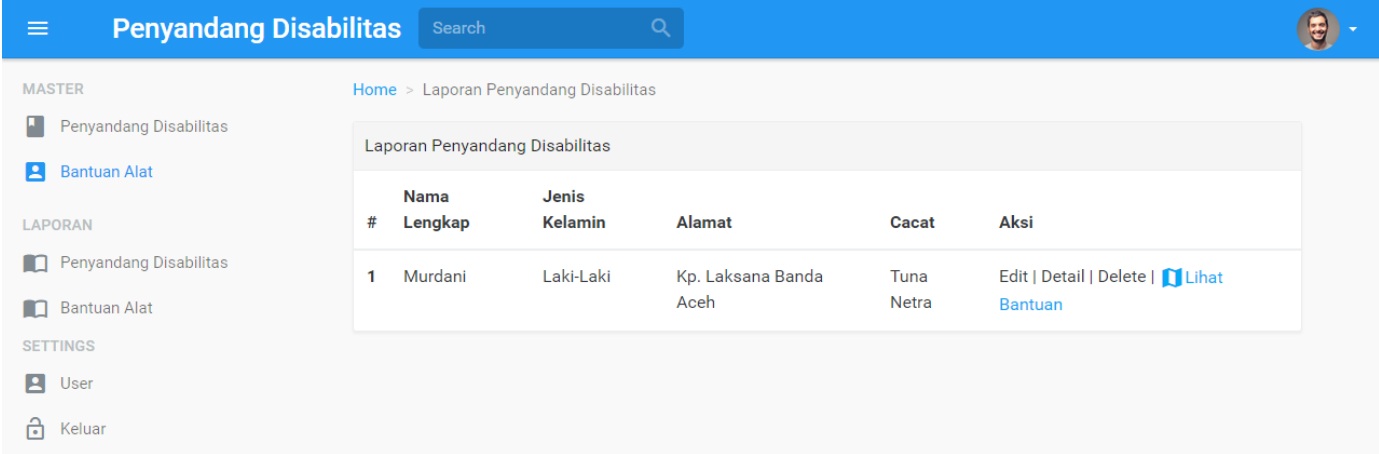

Gambar 6. Form Laporan Penyandang Disabilitas

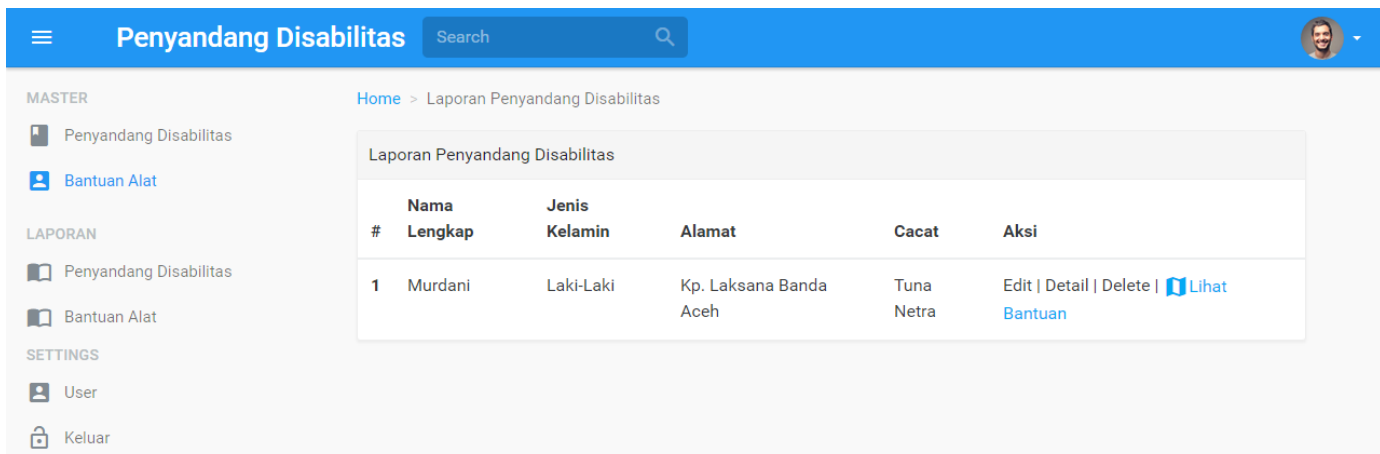

Gambar 7. Form Laporan Bantuan Alat Penyandang Disabilitas

3.6. Spesifikasi Hardware dan Software

Berikut ini adalah hardware dan software yang dibutuhkan untuk menggunakan program sistem Bantuan alat penyandang disabilitas, yaitu:

a. Hardware

Hardware yang dapat mendukung aplikasi ini memerlukan perangkat keras dengan spesifikasi:

1. CPU minimal pentium 3 dengan kecepatan $633 \mathrm{Mhz}$

2. Ram $256 \mathrm{MB}$

3. Hard disk minimal 1 GigaByte

4. Monitor 


\section{Keyboard dan Mouse}

6. Printer

\section{b. Software}

Software yang mendukung aplikasi ini diantaranya:

1. Windows 7,8,10, Linux, Symbian, Android

2. Browser (Mozilla, Google Chrome)

3. Xampp

\section{Kesimpulan}

Berdasarkan hasil pengamatan dan penulis dapat menarik suatu kesimpulan yang diantaranya adalah sebagai berikut:

a) Proses pendataan bantuan alat disabilitas dengan menggunakan sistem berbasis online lebih mudah dilakukan di Dinas. Karena adanya banyak data penyandng disabilitas dan bantuan sehingga dengan menggunakan sistem nomor maka kode yang diberikan tidak terbatas.

b) Sistem informasi bantuan alat bagi penyandang disabilitas menggunakan MySQL sebagai databasenya. sistem informasi bantuan alat bagi penyandang disabilitas dengan MySQL dapat mempermudah dalam pencarian (Dokumen, Penyandang, Bantuan Alat) dsb.

c) Dari keamanan data yang disimpan dalam sistem yang terkomputerisasi mempunyai tingkat keamanan yang tinggi karena dilengkapi dengan verifikasi pengguna (login user), sehingga hanya orang yang mempunyai hak akses saja yang dapat menggunakan.

d) Resiko kerusakan atau kehilangan data dalam sistem komputerisasi masih tetap ada, namun dalam skala yang relatif rendah. Untuk mengatasi hal ini dapat dilakukan backup data ke tempat penyimpanan lain selain harddisk komputer.

\section{Daftar Pustaka}

[1] Ngafifi, M., 2014. Kemajuan teknologi dan pola hidup manusia dalam perspektif sosial budaya. Jurnal Pembangunan Pendidikan: Fondasi dan Aplikasi, 2(1).

[2] Indrajit, R.E., 2000. Manajemen sistem informasi dan teknologi informasi. Jakarta: PT Elex Media Komputindo.

[3] Aswati, S. and Siagian, Y., 2016. Model Rapid Application Development Dalam Rancang Bangun Sistem Informasi Pemasaran Rumah (Studi Kasus: Perum Perumnas Cabang Medan. SESINDO 2016, 2016.

[4] Purnama, B.E., 2011. Sistem Informasi Kartuhalo Dari Telkomsel Berbasis Komputer Multimedia Kajian Strategis Praktis Telkomsel Divisi Surakarta. Speed-Sentra Penelitian Engineering dan Edukasi, 2(1).

[5] Simarmata, J., Chaerul, M., Mukti, R.C., Purba, D.W., Tamrin, A.F., Jamaludin, J., Suhelayanti, S., Watrianthos, R., Sahabuddin, A.A. and Meganingratna, A., 2020. Teknologi Informasi: Aplikasi dan Penerapannya. Yayasan Kita Menulis.

[6] Martono, N., 2010. Metode penelitian kuantitatif: Analisis Isi dan Analisis Data Sekunder (sampel halaman gratis). RajaGrafindo Persada.

[7] Jaedun, A., 2011. Metodologi penelitian eksperimen. Fakultas Teknik UNY, 12. 
[8] Muslihudin, M., 2016. Analisis Dan Perancangan Sistem Informasi Menggunakan Model Terstruktur Dan UML. Penerbit Andi.

[9] Mulyani, S., 2017. Metode Analisis dan perancangan sistem. Abdi Sistematika.

[10] Wali, M., 2020. Modul Praktikum Rekayasa Perangkat Lunak. Ellunar Publisher.

[11] Sutabri, T., 2012. Analisis sistem informasi. Penerbit Andi.

[12] Anggraeni, E.Y., 2017. Pengantar sistem informasi. Penerbit Andi.

[13] Purnomo, D., 2017. Model Prototyping Pada Pengembangan Sistem Informasi. JIMPJurnal Informatika Merdeka Pasuruan, 2(2).

[14] Ismail, I., Alfina, A., 2020. Modul Pemrograman Visual BASIC. KITA Publisher. 